\title{
Research Progress on Leptotrombidium deliense
}

\author{
Yan Lv', , Xian-Guo Guo ${ }^{1,2 *}$, Dao-Chao Jin ${ }^{1}$ \\ ${ }^{1}$ Institute of Entomology, Guizhou University, and the Provincial Key Laboratory for Agricultural Pest Management in Mountainous Region, Guiyang \\ 550025, P. R. China; ' Vector Laboratory, Institute of Pathogens and Vectors, Yunnan Provincial Key Laboratory for Zoonosis Control and Prevention, \\ Dali University, Dali, Yunnan Province 671000, P. R. China
}

\begin{abstract}
This article reviews Leptotrombidium deliense, including its discovery and nomenclature, morphological features and identification, life cycle, ecology, relationship with diseases, chromosomes and artificial cultivation. The first record of $L$. deliense was early in 1922 by Walch. Under the genus Leptotrombidium, there are many sibling species similar to L. deliense, which makes it difficult to differentiate $L$. deliense from another sibling chigger mites, for example, $L$. rubellum. The life cycle of the mite ( $L$. deliense) includes 7 stages: egg, deutovum (or prelarva), larva, nymphochrysalis, nymph, imagochrysalis and adult. The mite has a wide geographical distribution with low host specificity, and it often appears in different regions and habitats and on many species of hosts. As a vector species of chigger mite, $L$. deliense is of great importance in transmitting scrub typhus (tsutsugamushi disease) in many parts of the world, especially in tropical regions of Southeast Asia. The seasonal fluctuation of the mite population varies in different geographical regions. The mite has been successfully cultured in the laboratory, facilitating research on its chromosomes, biochemistry and molecular biology.
\end{abstract}

Key words: Chigger mites, Leptotrombidium deliense, vector, life cycle, ecology, scrub typhus

\section{INTRODUCTION}

Leptotrombidium deliense (Walch, 1922) is a species of chigger mite (chigger, trombiculid mite, tsutsugamushi mite, sand mite, grass itch mite, scrub itch mite or harvest mite), and it is the main vector of scrub typhus (tsutsugamushi disease) in many parts of the world but mostly in tropical regions of Southeast Asia [1-3]. Scrub typhus is a vector-borne disease and zoonosis caused by the agent Orientia tsutsugamushi (early names: O. tsutsugamushi or Rickettsia tsutsugamushi) and transmitted by chigger mites. Scrub typhus is widely distributed in the "tsutsugamushi triangle" region, which extends from northern Japan and far-eastern Russia in the north, to northern Australia in the south, and Pakistan and Afghanistan in the west [4-6]. More than a billion people are at risk of the disease, and nearly a million cases appear every year. It is prevalent in southeastern and eastern Asia, and all age groups (including children) are susceptible to the disease [7].

\footnotetext{
- Received 5 May 2018, revised 9 August 2018, accepted 10 August 2018.

*Corresponding author (xianguoguo@yahoo.com)

(C) 2018, Korean Society for Parasitology and Tropical Medicine

This is an Open Access article distributed under the terms of the Creative Commons Attribution Non-Commercial License (http://creativecommons.org/licenses/by-nc/4.0) which permits unrestricted non-commercial use, distribution, and reproduction in any medium, provided the original work is properly cited.
}

\section{DISCOVERY AND NOMENCLATURE}

Early in 1922, Walch described and named Trombicula deliensis under the genus Trombicula [8]. In 1952, Womersley revised the taxonomic position of the mite at subgenus level and changed its original name to Trombicula (Leptotrombidium) deliense [9]. In 1976, Vercammen-Grandjean and Langston revised its genus position and altered its scientific name to Leptotrombidium (Leptotrombidium) deliense deliense [10]. Based on former revisions, the scientific name of the mite was further amended as Leptotrombidium (Leptotrombidium) deliense, which can be abbreviated as L. (L.) deliense [11-13] or L. deliense [12,14].

In 1922, Walch reported scrub typhus transmitted by L. deliense in Sumatra, a prevalent region of the disease [8]. Some subsequent works proved that $L$. deliense was the vector of scrub typhus in various other places of the world, including Malaysia (reported by Fletcher in 1928), India (by Mehta in 1937), Australia (by Heaslip in 1941), China (by Millspauch and Fuller in 1947), and in the provinces of Burma and Assam in India (by Davis in 1947) [15-19]. Several other names for Leptotrombidium deliense, such as Leptotrombidium (Leptotrombidium) deliense deliense or Leptotrombidium deliense deliense, implied the probable differentiation of subspecies of the mite [10]. Besides L. deliense deliense, other "subspecies" of the mite under the genus Leptotrombidium, included L. deliense sinense 
Wen and Chen in 1984 [20] and L. deliense microsetosa Zhao in 1986 [21]. However, the "subspecies" of L. deliense sinense and $L$. deliense microsetosa were later proved to be synonyms of $L$. deliense described by Walch in 1922, i.e., not real subspecies [14]. To date, scientists have not confirmed the "subspecies" differentiation of $L$. deliense and future research is needed.

\section{TAXONOMY, MORPHOLOGY AND IDENTIFICATION}

In zoological taxonomy, L. deliense belongs to the subgenus Leptotrombidium, genus Leptotrombidium, subfamily Trombiculinae in the family Trombuculidae. In the complex life cycle of chigger mite, only the larva (simply called "chigger") is an ectoparasitic stage, which feeds on some other animals (hosts), especially rodents and several other small mammals. Therefore, the identification of chigger mites has long been based on the morphology of the larva [12].

The larva of $L$. deliense is very tiny $(200-400 \mu \mathrm{m})$ and it must be observed under a microscope for its identification. Specific morphological characteristics can help differentiate $L$. deliense (larval stage) from some other sibling species of the mites in the same genus [22]. For instance, the idiosoma of the larva $(L$. deliense) is usually oval in shape and salmon pink in appearance, and there is a distinct red ocellus on each dorsal side next to the scutum. The scutum is approximately rectangular in shape, with a concave anterior edge, 2 lateral edges and a slightly convex posterior edge. Sometimes, the convex posterior edge may have a micro-concave in the center. There are 5 plumose setae on the scutum, including $1 \mathrm{AM}(\mathrm{AM}=1), 2$ pairs of $\mathrm{AL}$ and PL ( $\mathrm{AL}=2, \mathrm{PL}=2)$. Two sensilla on the scutum are filiform with a naked base and 17-19 branches exist on the distal part of each sensillum. The SB is located in front of the connecting line between 2 PLs (SB/PLs). The remaining morphological characteristics include AP $(24-33 \mu \mathrm{m}) \leq \mathrm{SB}(26-36 \mu \mathrm{m})$, ASB $(24-31 \mu \mathrm{m}) \approx 2 \mathrm{PSB}(11-16 \mu \mathrm{m}), \mathrm{fDS}=2 \cdot 8 \cdot 6 \cdot 6 \cdot 4 \cdot 2=28$ and $\mathrm{VS}=20-22[12,14]$. Table 1 lists the abbreviations and the corresponding morphological structure of the larva of Leptotrombidium deliense $[9,12,14,23]$. Two photos of the larva, including the whole mite and its scutum, are shown in Figs. 1, 2.

Table 1. Abbreviation morphological structure of Leptotrombidium deliense larva (Walch, 1922)

\begin{tabular}{|c|c|c|c|}
\hline Abbreviation & Morphological structure of larva & Abbreviation & Morphological structure of larva \\
\hline AM & Anteromedian seta & ASB & $\begin{array}{l}\text { Antero-sensillary base distance } \\
\text { (distance between anterior edge of scutum and } \\
\text { sensillary base) }\end{array}$ \\
\hline$A L$ & Anterolateral seta & PSB & $\begin{array}{l}\text { Postero-sensillary base distance } \\
\text { (distance between posterior edge of scutum and } \\
\text { sensillary base) }\end{array}$ \\
\hline SB & Sensillary base distance (distance between 2 sensillary bases) & VS & Number of ventral setae \\
\hline $\mathrm{AP}$ & Distance between anterolateral seta and posterolateral seta & & \\
\hline
\end{tabular}

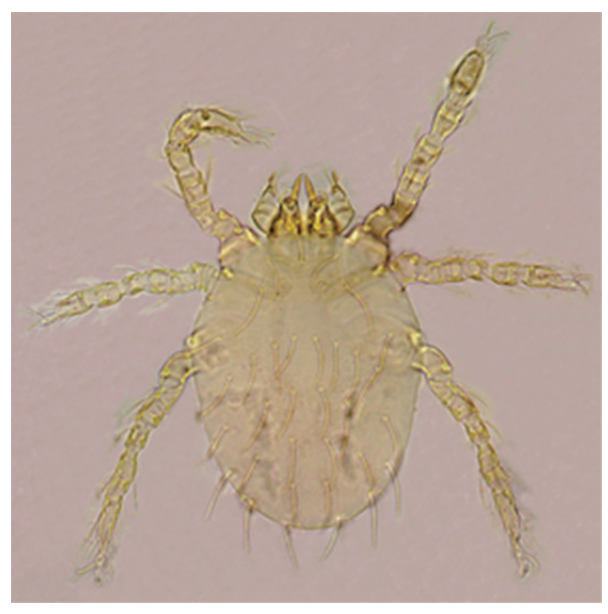

Fig. 1. Larva of Leptotrombidium deliense $(10 \times 20)$.

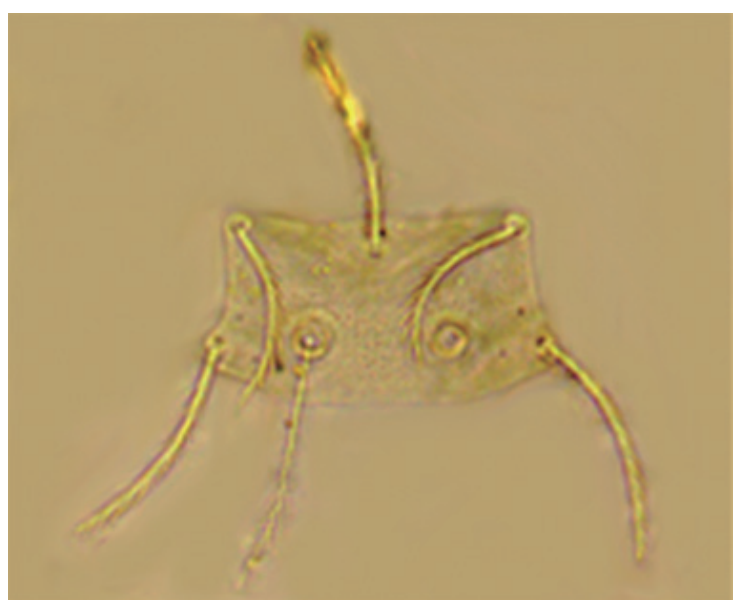

Fig. 2. Scutum of the Leptotrombidium deliense larva $(10 \times 40)$. 


\section{SIBLING SPECIES}

Leptotrombidium deliense is an independent species of chigger mite under the genus Leptotrombidium. There are many species in the genus Leptotrombidium, and a few are so similar in morphology that it is very difficult to differentiate one from another, for example, L. deliense, L. rubellum (Wang and Liao, 1984) and $L$. akamushi (Barumpt, 1910) and some other sibling species.

Early in 1959, Chinese scientists observed 2 "types" of $L$. deliense based on the external morphology, termed types A and B of $L$. deliense, in the Fujian province of China [24]. Following a series of studies on the morphological characteristics (including various measurements) of the larvae, the habitat investigation and hybridization of the adults, "type A" of L. deliense was finally proved to be an independent new species ( $L$. rubellum) and "type B" of $L$. deliense was the original $L$. deliense described by Walch in 1922. The hybridization between $L$. deliense and $L$. rubellum seldom occurs in laboratory experiments. The occasional hybridized offspring (F1 and F2 generations) have a very low survival rate and reproductive rate with malformations. The malformed larvae often present a series of deformed morphological structures, such as a deformed scutum, abnormal scutal setae and abnormal dorsal setae. The results of hybridization indicated reproductive isolation existed between $L$. deliense and $L$. rubellum $[14,25]$. It is now established that $L$. deliense and $L$. rubellum are sibling species that share a similar morphology. The scutum of $L$. deliense is rectangular-like with $\mathrm{SB}>\mathrm{AP}$ or $\mathrm{SB}=\mathrm{AP}$. The scutum of $L$. rubellum, however, is approximately square with the width $\approx$ length and $\mathrm{SB}<\mathrm{AP}$. As a practical identification, $\mathrm{SB}<\mathrm{AP}$ can be regarded as one of the key morphological features of $L$. rubellum that differentiates it from $L$. deliense with $\mathrm{SB}>\mathrm{AP}$ or $\mathrm{SB}=\mathrm{AP}$ [25]. A previous study showed that there were no significant differences in karyotypes between $L$. deliense and $L$. rubellum, and both 2 sibling species had a diploid karyotype, but different chromosomal band patterns [26]. Differences in G-band staining of chromosomes between $L$. deliense and $L$. rubellum revealed that $L$. deliense seemed more difficult to stain than L. rubellum. The techniques for esterase isoenzymes were once thought to be a supplementary way to study sibling species and subspecies in taxonomy. Polyacrylamide gel electrophoresis analysis (PAGE) evidenced some differences in the esterase isoenzymes between the larvae of $L$. deliense and $L$. rubellum, with 8 main enzyme bands in $L$. deliense and 6 main enzyme bands in L. rubellum, as well as different sub-bands of esterase isoenzymes under each "main enzyme band" between the 2-sibling species [26]. In addition, the zymogram for esterase isoenzymes of the 2 , sibling species ( $L$. deliense and $L$. rubellum) was close to that of $L$. pallidum, another independent species in the genus Leptotrombidium [27].

The hybridization between $L$. deliense and L. akamushi happened once in the laboratory, producing F1 and F2 generations (F1ad and F2ad) by successful mating (hybridization) between $L$. deliense ( $\delta^{\lambda}$ ) and L. akamushi ( $(+)$. The scutal measurements showed that F1ad shared characteristics of their 2 parents, but the morphology of F1ad and F2ad was much more similar to L. deliense (male parent) than L. akamushi (female parent) [28]. Both mite species, L. deliense and L. akamushi, belong to the same genus, Leptotrombidium, and they can be differentiated from each other through the following morphological features. In L. deliense, $\mathrm{fDS}=2 \cdot 8 \cdot 6 \cdot 6.4 .2=28$, the arrangement and number of fDS are generally stable, and $\mathrm{VS}=20-22$. In L. akamushi, however, $\mathrm{fDS}=2.8 .6$ (8)... or 2.10.8. 8.6.2 $=32-40$, the number of fDS in the second column varies greatly in different individuals, and VS=22-36. The body size of $L$. akamushi is larger relative to $L$. deliense, and L. akamushi has longer setae and sensillae than $L$. deliense $[12,28,29]$.

Besides L. rubellum and L. akamushi, a few other chigger mite species in genus Leptotrombidium are often confused with $L$. deliense in the identification, for example, L. subangi (Vercammen-Grandjean and Langston, 1976), L. bunaense (Wormersley, 1952), L. umbricola (Nadchatram and Dohany, 1980) and $L$. vivericola (Vercammen-Grandjean and Langston, 1976). Of these affinis species or sibling species of $L$. deliense, $L$. vivericola or $L$. (L.) vivericola were suspected to be an important transmission vector of scrub typhus in Peninsular Malaysia [30]. The early literature proposed that "species group of deliense" should include L. deliense, L. deliense subangi, L. arenicola, L. vivericola, L. vanderghinstei and L. vanderghinstei austral [10]. The latest report, however, presented that "species group of deliense" included L. subangi, L. sialkotense (= L. jishoum Wen, Li, Zhang \& Liao, 1988, syn. nov.), L. spicapilum, L. paulum, L. pentafurcatum and L. deliense [14]. The mite L. subangi was morphometrically close to $L$. deliense, but it had less barbed body setae and shorter specialized leg setae [10]. Leptotrombidium bunaense was previously considered to be the synonym of $T$. (L.) deliensis form bunaensis (a "type" of $L$. deliense), but Wormersley believed that $T$. ( $L$.) deliensis form bunaensis was an independent species of genus Leptotrombidium, which was named as L. bunaense (Wormersley, 1952). Although VercammenGrandjean later presented a new name for this species, it be- 
longs to the synonym of $L$. bunaense. The main differences between $L$. bunaense and $L$. deliense focused on lengths of 2 setae, notably, the PL length, as follows. The average PL of the former (L. bunaense) is $85 \mu \mathrm{m}$ and $\mathrm{fDS}=2.8 \cdot 6 \cdot 6 \cdot 8 \cdot 6.4 .2=42$, but the average PL of the later ( $L$. deliense) is $54-56 \mu \mathrm{m}$ and $\mathrm{fDS}=2.8$. 6.6.4.2 $=28$ [31]. As a member of "species group of deliense", $L$. umbricola, also called $L$. (L.) umbricola [10], is another sibling species of $L$. deliense. Leptotrombidium umbricola has similar morphology and habitats to $L$. deliense, but it has a smaller body size and smaller dimensions of scutum and legs. The scutal punctation pattern and VS arrangement in L. umbricola also differs from $L$. deliense, as follows: $\mathrm{VS}=8.4 .4$ (or 8.6.2) $=16$ and $\mathrm{IP}=630-646 \mu \mathrm{m}$ (here $\mathrm{IP}=$ index of poda) in L. umbricola while VS=20-22 and $\mathrm{I} P=728 \mu \mathrm{m}$ in L. deliense [30]. From the host preference, habitat distribution and infection rate with $O$. tsutsugamushi within unengorged specimens, it was suggested that $L$. umbricola or $L$. (L.) umbricola might also be an important vector of scrub typhus in Peninsular Malaysia [30]. Leptotrombidium deliense is also closely related to $L$. pentafurcatum and $L$. paulum. Leptotrombidium paulum has 2 branched galeal setae with $\mathrm{PL}=\mathrm{AM}$ and $\mathrm{AM}-\mathrm{AL}=15$. Some specimens of $L$. pentafurcatum (part) have 5 galeal setae with long branches with $\mathrm{PL}>\mathrm{AM}$ and $\mathrm{AM}-\mathrm{AL}=8$. Leptotrombidium deliense, however, has more than 5, branched galeal setae with $P L \geq A M$ and AM-AL=6-11 [14]. Takahashi (2014) studied different "geographical types" of $L$. deliense, Miyako-L. deliense and Naka- $L$. deliense, in different geographical regions. In control groups, all females of Miyako-L. deliense and Naka-L. deliense could independently lay their eggs without any cross-mating or hybridization. Of 5 pairs of "cross-mating" mites between Miyako- $L$. deliense females ( $(+)$ and Naka-L. deliense males $\left({ }^{\lambda}\right)$, however, none of them laid eggs. Therefore, reproductive isolation (genital isolation) was considered to exist between these 2 "geographical types” of $L$. deliense, Miyako- $L$. deliense and Naka- $L$. deliense. Based on scutum structure, AW, PW and a longer PS, Naka-L. deliense was separated from Miyako-L. deliense, Malaysia-L. deliense and Thailand-L. deliense, in 3 different geographic regions. In addition, the chromosome number of Naka- $L$. deliense $(2 \mathrm{n}=14)$ also differed from that of Miyako-L. deliense chromosomes $(2 n=16)$ [32]. Considering the morphological and chromosomal differences, Takahashi (2014) suggested that Naka-L. deliense could be defined as a new species: L. suzukii sp. nov. [31].

\section{LIFE CYCLE}

\section{Life cycle process}

Like all species of chigger mites, there are 7 stages in the life cycle of $L$. deliense, including the egg, deutovum (or prelarva), larva, nymphochrysalis, nymph, imagochrysalis and adult (male and female) (Fig. 3). Of the 7 stages, only the larvae are ectoparasitic (ectoparasites), whereas the other 6 stages are free-living in topsoil. Small mammals, especially rodents, are the most common hosts of $L$. deliense larvae [12]. Under laboratory conditions of about $25-30^{\circ} \mathrm{C}, 100 \%$ relative humidity (RH) and adequate food supply, the development of $L$. deliense was observed by some scientists, as follows: previposition period (5-9 days, simply 5-9 days), egg (4-8 days, average 6 days), deutovum (7-14 days, average 10 days), larval parasitism (2-7 days), post-parasitism (1-4 days), nymphochrysalis (12-14 days, average 12 days), nymph (10-35 days, average 17 days), imagochrysalis (7-15 days, average 12 days) and adult stage (more than 58-245 days). The duration required for a complete generation of $L$. deliense was 59-135 days (average 89 days). In the first stage of the life cycle, eggs of $L$. deliense hatch on the surface of soil habitat at the appropriate temperature in about 4-8 days (average 6 days). This hatching process includes the formation and enlargement of the ovum embryo,

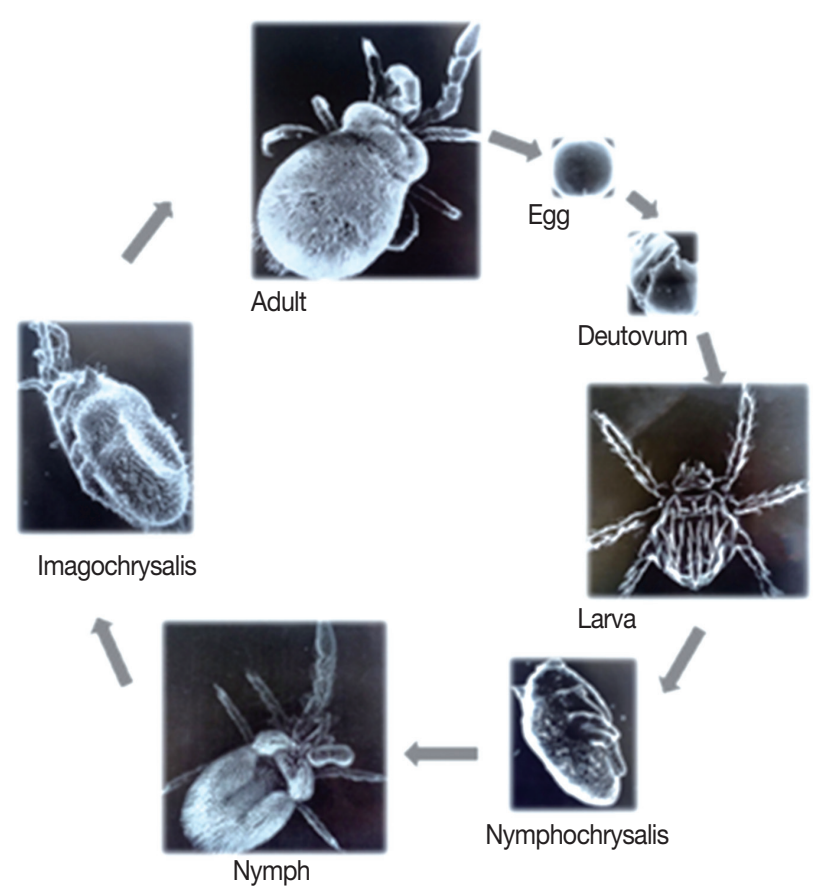

Fig. 3. Seven stages in the life cycle of Leptotrombidium deliense. 
from the ball shape turning into the oval shape. In the next 7-14 days (average 10 days) of development, the larva matures, and the eggshell ruptures to release a "newborn larva" (neonate larva or newly hatched larva). After rupturing out of the diaphragm, the newborn larva crawls to the highest surface of mud or climbs onto grass leaves waiting for a host. On meeting an appropriate host, the newborn larva clings and attaches to the thin and moist skin of the host, stings the host and sucks the host's lymph or tissue liquid. After 2-3 days sucking, the "newborn larva" enlarges dozens of times in size and becomes an "engorged larva", which then falls off the host onto the ground and develops into a nymphochrysalis, nymph, imagochrysalis and adult (male and female). The females produce their eggs in crevices of top soil and usually produce 100200 eggs in their life time $[12,23,33]$. The lifespan of $L$. deliense is about 15-81 days (mean 44 days) for males and 75-107 days (average 91 days) for females [34].

\section{Growth and development}

The temperature has proven to be a key factor affecting the life cycle development of $L$. deliense [12,23,33,35]. Some previous studies showed that the critical temperature for the development and reproduction of $L$. deliense was 13 and $35^{\circ} \mathrm{C}$, respectively, and the optimum temperature was $18-28^{\circ} \mathrm{C}[23,35]$. The optimum temperatures were $23-25^{\circ} \mathrm{C}$ for larval activities and $18-30^{\circ} \mathrm{C}$ for disease transmission. The suitable RH for development and reproduction was $95-100 \%$. Under the temperature range of $13 \pm 1-35 \pm 1^{\circ} \mathrm{C}$, L. deliense can complete the whole life cycle process. The optimum temperature under which the hatching rate of larvae was highest appeared to be $23 \pm 1^{\circ} \mathrm{C}$ $[12,23,35]$. When the RH was fixed at $95-100 \%$, both the egghatching rate and development speed of the chigger mite ( $L$. deliense) were consistent with the increase of temperature within the suitable temperature range, that is, the higher the temperature was, the higher the hatching rate and the quicker the development speed. Based on available temperature information in different seasons, it would be possible to predict the fluctuation of females' fecundity, egg-hatching rate and egghatching period, among others $[9,23,33]$.

\section{Feeding habits}

Similar to many other species of chigger mites, $L$. deliense has 3 feeding stages (active stages), larva, nymph and adult, in its complex life cycle, and the rest of the stages (prelarva, nymphochrysalis and imagochrysalis) are non-feeding or quiescent stages. It means that there is a non-feeding stage (quiescent stage) before every feeding stage (active stage) in the life cycle of $L$. deliense. As one of 3 feeding stages, the larva is the only ectoparasitic stage (ectoparasite), and it lives on the body surface of some other animals (hosts) and feeds on the lymph, tissue fluid and decomposed tissue cells of its hosts [7]. The adult (male and female) and nymph of $L$. deliense have the same feeding habits, and they usually feed on numerous small insects and their eggs. Occasionally, the adult and nymph can "eat" eggs of some other chigger mites, including the same and different species of chigger mites. Under laboratory conditions (artificial feeding conditions), most adults and nymphs of $L$. deliense were found to prefer fresh eggs of fleas to eggs of some other insects [19]. When the adult and nymph are very hungry, they may reluctantly ingest eggs of several other insects, for example, eggs of mosquitos. In the laboratory, the fecundity (female's egg production), egg-hatching rate and lifespan of $L$. deliense was negatively influenced (much lower or shorter) when mosquito eggs were used as food for the adult and nymph [12]. Besides flea eggs, however, the adult and nymph of $L$. deliense may also feed on some other arthropods as one of their food sources, e.g., the order Collembola and Isopoda in the natural environment $[12,33]$.

\section{Mating behavior and oviposition}

Some experimental investigations previously reported the following mating behavior and oviposition of $L$. deliense $[9,12,23,33]$. A male $L$. deliense began to produce spermatophores within 2-7 days after emerging from an imagochrysalis. The spermatophore production lasted 3-52 days (average 30 days) in the lifetime of the mite. Each male of the mite (L. deliense) produced an average 60-70 spermatophores during its life and the maximum production reached 150 spermatophores per male $[9,12]$. A spermatophore is composed of 2 parts, a sperm ball and sperm filament. The sperm ball is a round, orangered and capsule-like structure of $27 \mu \mathrm{m}$ in diameter, containing semen and sperms (spermatozoa). The sperm filament is a colorless, transparent and silk-like structure of $89 \mu \mathrm{m}$ in length. The top of the sperm filament is branched, forming a distinctive "sperm tray" to support the sperm ball, and the base is a tree-like structure that "roots" in crevices of top soil. When a female $L$. deliense encounters the sperm ball with sperms (spermatozoa), the female lifts its body, crawls over the sperm ball and takes the sperm ball with its palps into its genital pore. This process is often described as "indirect mat- 
ing" or "indirect fertilization", which is usually finished in 5-8 days. The pregnant female lays its eggs in the top soil, 7-25 days after the fertilization (indirect fertilization). The oviposition process (egg production) may last 8-253 days or longer (average 30-40 days). A female $L$. deliense generally produces 1-3 eggs/days and the maximum production may reach 12 eggs/days, and it can produce 229-4,450 eggs for the whole lifetime. After finishing its egg-laying, the female often stirs the top soil to make its eggs "dirty" and then hide its eggs in the soil. The oviposition (egg production) is greatly influenced by the environmental temperature. At $100 \% \mathrm{RH}$, the number of eggs produced by the female mites is decreased with the increase of temperature within the temperature range of $25-30^{\circ} \mathrm{C}$ $[12,36]$. It was reported that the development and reproductive capacity of $L$. deliense could be impaired by the radioactive isotope ${ }^{60} \mathrm{CO} \gamma$ rays. Some dose of ${ }^{60} \mathrm{CO} \gamma$ rays $(0.64 \mathrm{C} / \mathrm{kg} \gamma)$, however, could induce a specific mutated strain of $L$. deliense, which retained its reproductive ability but could not transmit scrub typhus [37]. Different seasonal temperatures can give rise to a seasonal fluctuation of oviposition and egg-hatching. In subtropical regions, female adults can keep laying eggs even in winter, but very few eggs can hatch larvae. The oviposition peak may be from March to May when the most abundant larvae are hatched from the eggs. From August to September, however, egg-laying and egg-hatching decline $[23,38]$. It is said that $L$. deliense may have parthenogenesis [39]. This production of different mite "strains" of the same species in the natural environment is likely to be a source of confusion regarding different species in the taxonomy.

\section{ECOLOGY}

\section{Activity and behavior}

Leptotrombidium deliense was observed to be more active in the morning and evening than in the noon and afternoon, showing a daily rhythm of activity, which was influenced by a series of environmental factors. When strong light and weak light were designed to coexist in the laboratory, most $L$. deliense crawled to the side of weak light at a moving speed of 10 $\mathrm{cm} / \mathrm{min}$, and this implied that this species of chigger mite seemed to have a slight phototaxis to weak light. In the laboratory, the crawling speed of the mite (L. deliense) becomes increasingly slower when the temperature gradually decreases, and the activity of the mite stops when the temperature drops below $13^{\circ} \mathrm{C}[9,12,23]$. Humidity plays an important role in in- fluencing the vitality of $L$. deliense. The newborn larvae (newly hatched larvae) of L. deliense were observed to have a preference to wet habitats, and the larvae were suggested to be preserved in a warm $\left(28-30^{\circ} \mathrm{C}\right)$ and humid $(85-90 \% \mathrm{RH})$ environment [33]. When the temperature was fixed at $25 \pm 1^{\circ} \mathrm{C}$, the survival time of the newborn larvae lengthened when the $\mathrm{RH}$ gradually increased. For example, the newborn larvae survived for $12.06 \pm 0.30 \mathrm{hr}$ at $20 \% \mathrm{RH}$ compared to $12.37 \pm 0.40 \mathrm{hr}$ at $30 \% \mathrm{RH}$. When the RH went up to $100 \%$ at $25 \pm 1^{\circ} \mathrm{C}$, the survival time of the newborn larvae was prolonged to $7.78 \pm 0.28$ days [12]. The number of adults and nymphs of $L$. deliense is positively correlated with that of some other arthropods, e.g., the order Thysanura and Isopoda, in the natural habitat. The number of Thysanura and Isopoda might directly influence the growth, development, reproduction and seasonal population fluctuation of $L$. deliense $[9,12]$. The radioactive isotope $\left({ }^{32} \mathrm{P}\right)$ was reported to be used in following the activity of $L$. deliense in soils, according to the radioactivity of the labeled radioactive elements [40].

\section{Host selection}

As the only parasitic stage in the life cycle, the larvae of chigger mites (chiggers) live on the body surface of some other animals. Due to their low host specificity, a variety of animals, among mammals, aves, reptiles, amphibians and even some other arthropods could be the hosts of chiggers $[9,23]$. Small mammals (mainly rodents), however, are the most common hosts of chiggers. Chiggers are usually a prevalent group of ectoparasites on the body surface of rodents (rats, mice and squirrels) and some other small mammals, e.g., insectivores and tree shrews. When chiggers live on the body surface of warm-blood animals (mammals and aves), they feed on the lymph, body fluid and decomposed tissue of their hosts through their sucking activity $[2,19]$. Similar to most species of chigger mites, $L$. deliense also have a wide range of hosts with low host specificity. To date, more than 30 species of small mammals (mainly rodents and insectivores) and birds have been reported to be the hosts of $L$. deliense [12,23]. Of the various species of rodents (order Rodentia), the following species are the common hosts of L. deliense: Apodemus agrarius, A. chevrieri, Dremomys pernyi, Eothenomys miletus, E. custos, Mus pahari, Niviventer confucianus, $N$. fulvescens, $N$. andersoni, Rattus tanezumi ( $R$. flavipectus), $R$. norvegicus, $R$. losea, $R$. rattus, $R$. brunneusculus (R. sladeni), R. nitidus, $R$. bowersi, among others $[2,19,41,42]$. Besides many species of rodents, some species in 
the order Insectivora (insectivores) and Scandentia (tree shrew) are also important hosts of the mite, L. deliense, for example, Anowrosorex squamipes, Crocidura dracula, C. attenuata, Hylomys suillus, Neotetracus sinensis and Suncus murinus. The tree shrew (Tupaia belangeri) in the order Scandentia and some carnivores (e.g. Mustela kathiah) can harbor $L$. deliense as well. The main hosts of $L$. deliense vary in different geographical regions, landscapes and habitats. In Yunnan province of Southwest China, some rodent species in the genus Rattus were found to be the most common hosts of $L$. deliense, including A. agrarius, $A$. chevrieri, D. Pernyi, E. custos, E. miletus, M. pahari, N. confucia$n$ nus, $N$. dersoni, N. fulvescens, $R$. bowersi, $R$. brunneusculus ( $R$. sladeni), R. norvegicus, $R$. nitidus and $R$. tanezumi (R. flavipectus). The surveillance of small mammals from the Litchfield Park in northern Australia, however, showed that $L$. deliense had a comparatively higher infestation rate in 3 native species of rats, R. colletti, R. tunneyi and Melomys burtoni [43]. In the Peninsula of Malaysia, $R$. argentiventer and $R$. tiomanicus were considered to be the main hosts of $L$. deliense with much more individuals of $L$. deliense found on $R$. argentiventer than on $R$. tiomanicus [44]. Leptotrombidium deliense and some other species of chigger mites, together with a number of rodent species (particularly the species in the genus Rattus), have been considered as the suitable hosts of scrub typhus in the natural environment, and once inside, the pathogen of scrub typhus could not be eradicated by the hosts [45].

\section{Geographical distribution and habitat selection}

Leptotrombidium deliense has a preference for warm and humid environments. It is mainly distributed in tropical, subtropical and temperate zones of Asian-Pacific regions, where a billion people are at risk of scrub typhus with nearly a million

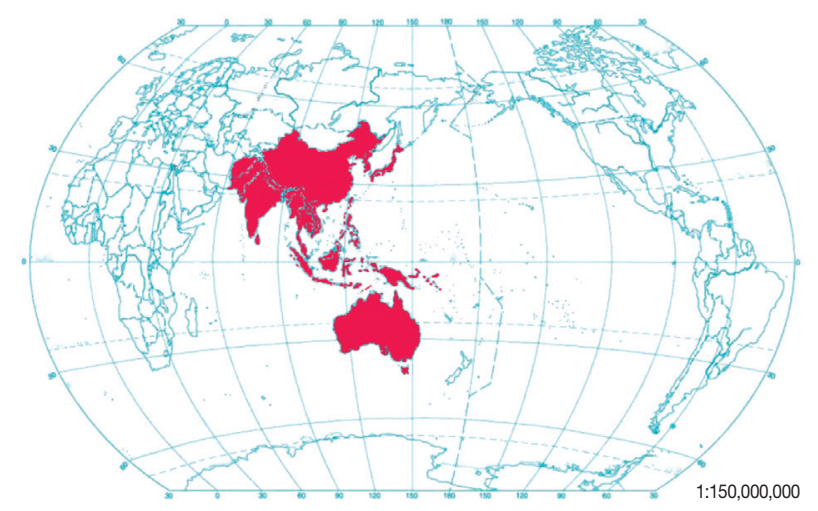

Fig. 4. Geographical distribution of Leptotrombidium deliense and scrub typhus. cases reported annually. The distribution of $L$. deliense includes Japan, China, the Philippines, Australia, India, Pakistan, Afghanistan and even some parts of Russia (see Fig. 4 for the geographical distribution of Leptotrombidium deliense and scrub typhus). The vectors of scrub typhus are L. deliense and Leptotrombidium akamushi, which are present in most countries of the South-East Asian region and they are endemic in certain geographical regions of India, Indonesia, the Maldives, Myanmar, Nepal, Sri Lanka and Thailand [7]. In some complex topographical regions with mountains, hills, rivers, valleys, plains and flatlands, the mite $L$. deliense prefers to be distributed in plains, flatlands and valleys with low altitude, hot temperature, high humidity and precipitation. The separated distribution areas may form a unique dotted distribution pattern, which is sometimes described as "mite islands". The distribution of $L$. deliense is highly associated with the activity and distribution of its hosts, some rodent species, for example. This species of chigger mite (L. deliense) is common in some coastal areas and islands of Asian-Pacific regions with low altitude and hot weather. In some mountainous areas with high altitude, however, some other dominant species of chigger mites often take the place of $L$. deliense because of cold and dry weather [42]. Several investigators roughly divided various habitats into 2 types, the indoor habitat (houses, barns and stables) and outdoor habitat (paddy fields, various farmlands and cultivated habitats, uncultivated bush habitats, woodlands and forests, etc.), and found that $L$. deliense was distributed in both habitats, but mainly outdoors $[19,41,42]$. Other studies stated that L. deliense could be spread to some new places with heavy rain or flood because it could survive for a few days in fresh water or seawater [7,41].

The investigation from Yunnan province in Southwest China revealed both species composition and dominant species of chigger mites differed in different geographic regions and habitats. Nonetheless, L. deliense was the dominant species of chigger mites in some places of Yunnan, especially in some flatlands and valleys along rivers with low altitude, hot and humid weather $[2,41,42]$. As one species of chigger mites in the family Trombiculidae, Leptotrombidium deliense has been proved to be the main vector of scrub typhus in many parts of Southeast Asia where scrub typhus, caused by the agent of $O$. tsutsugamushi infection, is the second common febrile disease next to malaria. In recent years, scrub typhus has been the most common re-emerging rickettsial infection in India and many countries in Southeast Asia [46]. There have been several 
major outbreaks of scrub typhus throughout India, and the principal vector has been confirmed to be L. deliense $[13,47]$. The district of Darjeeling in India was historically an epidemic focus of the scrub typhus in the 1960s, and L. deliense was considered as the major vector in the epidemic areas. The later investigations, however, added that there might be other vector species of chigger mites, besides $L$. deliense, in some parts of Darjeeling and other areas in India, for example, a large number of Schoengastiella ligula were found in Kurseong. The main vector of chigger mites may vary in different epidemic areas of scrub typhus in India, not always L. deliense. Schoengastiella ligula was suspected to be another important vector of scrub typhus in some parts of India [47]. Leptotrombidium deliense has also been reported in the eastern part of the Himalayas [48], Malaysia Peninsula and in Bastar District, Madhya Pradesh, India [49], where scrub typhus was prevalent.

\section{Seasonal fluctuation}

In the late 1950s, the larvae of $L$. deliense in the south of China displayed seasonal fluctuation with 2 peaks: the first peak appeared between June and July, and the second peak between September and October each year. The tendency of the mite fluctuation was consistent with the seasonal prevalence of scrub typhus [23] and closely related to the seasonal changes of local climate. Therefore, $L$. deliense would have different patterns of seasonal fluctuation in different geographical regions. In some southern provinces of China, $L$. deliense began to appear in April with the peak between June and August, and then gradually decreased after September. This seasonal fluctuation of the vector mite (L. deliense) was also in accordance with the seasonal prevalence of scrub typhus in the local foci [23]. Another report showed that $L$. deliense often appeared in humid seasons in 1 year [50]. Also, the prevalence risk of scrub typhus would become much higher in the peak seasons of the vector mite, and only a small number of chigger attachments were needed to infect potential hosts [50].

\section{MEDICAL IMPORTANCE}

Leptotrombidium deliense can give rise to a direct impairment when it stings the hosts (including human beings). The stinging and sucking activity of the mite will lead to the coagulation necrosis of peripheral tissue and finally form a "skin eschar". Sometimes the direct impairment caused by chigger mites (including L. deliense) is called trombidosis. The most medical importance of chigger mites, however, is their indirect impairment as the vectors of scrub typhus and potential vectors of some other zoonoses (e.g., hemorrhagic fever with renal syndrome, which is also called epidemic hemorrhagic fever, in China), not the direct impairment.

\section{Scrub typhus}

Scrub typhus is an acute febrile zoonosis caused by $O$. tsutsugamushi. Chigger mites are the only transmission vector of scrub typhus [41]. Human infection can occur through the sting by chiggers (the larvae of chigger mites) carrying $O$. tsutsugamushi. The common clinical manifestations of scrub typhus include chills and high fever, with a headache and aching muscles, eschar or ulcers, enlarged lymph nodes and skin rashes. The enlargement of lymph nodes and skin rashes are common clinical signs and the eschar on the skin is specific for the disease $[7,46]$. Some serious complications may develop in the course of the disease, such as myocarditis, pneumonia, meningoencephalitis, acute renal failure, gastrointestinal bleeding and even acute respiratory distress syndrome. Tetracycline and chloramphenicol are still powerful in the treatment of scrub typhus and are often the first therapeutic choices [12]. As a dominant species of chigger mites, the seasonal fluctuation of $L$. deliense is often consistent with the occurrence of scrub typhus. Based on a series of evidence, $L$. deliense is verified to be the most important vector in many foci of scrub typhus. The natural infection of $L$. deliense with $O$. tsutsugamushi (the agent of scrub typhus) has been confirmed in many parts of the world, including China, India, Myanmar, Thailand, Malaysia, Indonesia, the Maldives, Nepal, Sri Lanka, Thailand and its nearby islands, Australia, New Guinea, Pakistan and the Philippines $[46,51]$. Scrub typhus is widely prevalent in a confined geographical realm in the Asia-Pacific region, which is often described as the "tsutsugamushi triangle". The tsutsugamushi triangle is distributed over a very wide area of 13 million $\mathrm{km}^{2}$, bound by Japan in the east, through China, the Philippines, tropical Australia in the south, and west through India, Pakistan, possibly to Tibet to Afghanistan, and southern parts of Russia in the north $[7,22]$.

\section{Evidence for an effective vector of scrub typhus}

It has been confirmed that chigger mites are the only vectors of scrub typhus. To date, there have been more than 3,000 species of chigger mites recorded throughout the world, but not all the chigger mite species can be the effective vector of the 
disease. A body of evidence is usually required to prove if a species of chigger mite can be an effective vector of scrub typhus, as follows. (1) The suspected chigger mite species should be the dominant species, with abundant individuals in an epidemic focus. The distribution areas and seasonal fluctuation of the mite should be consistent with the occurrence of the disease. (2) From the natural population of the suspected chigger mite species, the agent of the disease, O. tsutsugamushi, can be successfully detected or isolated. (3) All the transmission can be done and repeated in the laboratory, including artificial infection, stinging transmission and transovarial transmission [52-54]. The transovarial transmission means that the pathogen, O. tsutsugamushi, can be passed from female chigger mites to their offspring (the next generation) through their egg production. The transovarial transmission is necessary for an effective vector of scrub typhus. In the life cycle of chigger mites, only the larva is in an ectoparasitic stage, and it feeds on the host's lymph, body fluid and decomposed cells and tissue, through its stinging and sucking activity. It has been demonstrated that the larvae of chigger mites (chiggers) sting and suck their hosts only once in their lifetime. Occasionally, the chiggers might sting and suck their hosts for the second time, but it was seldom observed in previous studies [12]. When the first generation of the larvae sucks and obtains the pathogen of scrub typhus (O. tsutsugamushi), the pathogen must be transferred to the second generation of the larvae, otherwise, the transmission process will not be completed, and the suspected chigger mite will not be an effective vector $[7,12,54]$.

\section{Scrub typhus and $L$. deliense}

In the many epidemic foci of scrub typhus, $L$. deliense is the dominant species in the localities, and the distribution areas and seasonal fluctuation of the mite have also been proved to be consistent with the occurrence of the disease [46,51]. In the natural epidemic foci of scrub typhus, the pathogen of the disease (O. tsutsugamushi) has frequently been detected and isolated [46]. In the laboratory, a complete transmission process could be finished and repeated in $L$. deliense. The larvae of $L$. deliense become infected after stinging and sucking infected rats with $O$. tsutsugamushi. The infected larvae pass $O$. tsutsugamushi to the next stages in the life cycle (nymphochrysalis, nymph, imagochrysalis, male and female adults) through "trans-stadial transmission", and then to the next generation of larvae through the transovarial transmission. The infected larvae of the next generation sting and suck healthy rats, there- by the healthy rats become infected, completing the transmission $[7,46]$. The positive strains of $L$. deliense collected from the epidemic foci can sting and suck new hosts (human beings and some other mammals) and finish the transmission of the disease, scrub typhus [46,51]. In the process of artificial transmission, a large number of $O$. tsutsugamushi (Karp type) were detected in the body of $L$. deliense by some researchers, and $O$. tsutsugamushi was mainly concentrated in the reproductive system of the female mite, e.g., ovary and uterus. The pathogenpositive chigger mites can be obtained directly by injecting $O$. tsutsugamushi into the body of the adult mites, and then the adult mites pass the pathogen to the larvae through the transovarial transmission $[7,55]$. Some scientists observed that male adults of $L$. deliense inoculated with $O$. tsutsugamushi could pass the pathogen $(O$. tsutsugamushi) to the female mites through mating activity and then to the offspring (eggs and larvae) of the next generation, and this process was described as "transorchial (vertical) transmission" or "trans-spermatophoral transmission" [34]. Based on a series of evidence, L. deliense has now been confirmed to be an effective vector of scrub typhus. In the vast areas of southern China, $L$. deliense is the main vector of the disease [12].

\section{Influence of $O$. tsutsugamushi infection on $L$. deliense}

The O. tsutsugamushi infection seems to have different influences on its rodent hosts (rats and mice) and vectors (including $L$. deliense). The infected rats (R. rattus) seemed "normal" without obvious manifestations but showed a slight increase of immunoglobulin (Ig)M antibody 2 to 6 weeks after the artificial infection and a noticeable increase of $\operatorname{IgG}$ antibody 2 to 19 weeks after the infection. The O. tsutsugamushi was successfully isolated from the rat $R$. rattus 1 to 8 weeks after the stinging by the O. tsutsugamushi-positive mite L. deliense, and the infected rats had no clinical manifestations and exhibited normal behaviors [52]. The infected laboratory mice (Mus musculus), however, died 14 days after the infection [52]. Female mites ( $L$. deliense) infected with $O$. tsutsugamushi also seemed normal relative to uninfected mites, and both the infected and uninfected mites had the same fecundity, namely, the same quantity of egg production [53]. The inoculated adults of $L$. deliense with $O$. tsutsugamushi (Hayashi type) showed no abnormal reactions with the persistence of $O$. tsutsugamushi in the mites for 14 days, and $O$. tsutsugamushi was passed to the third generation of the mites with $100 \%$ of cross-transmission among different generations through the transovarial transmission [54]. 


\section{CHROMOSOMES}

Some literature studies revealed the chromosomal karyotype of L. deliense is $2 \mathrm{n}=14$. The 7 pairs of chromosomes are small rodlike structures. The sizes of chromosomes gradually decreased from Nos. 1 to 7, without distinct large ones. Most chromosomes are metacentric, and a terminal satellite can be observed on the end of the No. 2 chromosome. The sex determination mechanism may be XX-XY with XX for females and XY for males, but it is usually very difficult to differentiate between the $\mathrm{X}$ and $\mathrm{Y}$ chromosomes $[26,56]$. Chinese scientists once reported a mutated strain of $L$. deliense, possessing a white body. This "white mutated strain" had an aberrated No. 6 chromosome and a high reproductive capacity for 3 generations [57]. It was reported that $L$. deliense had some differences in the tRNA-glutamine gene (trnQ) from its sibling species, L. pallidum. Unlike L. pallidum (4 LNR), $L$. deliense has no extra rrnL or PrrnS but has only 2 extra LNR [58]. The simplest scenario for this evolution involves 2 mechanisms: tandem duplication of a section of the genome, followed by random deletion of excess genes and nonhomologous intergenomic recombination. A third mechanism, gene conversion, is required to account for the concerted evolution of the duplicate or quadruple LNRs that have opposite orientations of transcription in each species of Leptotrombidium [58].

\section{ARTIFICIAL CULTURE}

The artificial culture of $L$. deliense has been very successful and it can produce more than 100 generations of the mite in the laboratory. The artificial strains of $L$. deliense usually have more than $90 \%$ hatching rate and emerging rate. The laboratory mice have been the conventional laboratory animals for the food source of the mite $[9,12,59]$. According to the living behaviors in the life cycle of chigger mites, the artificial culture of $L$. deliense usually includes 2 stages. In the first stage, the newly hatched larvae are placed onto the body surface of suitable hosts (usually laboratory mice) to let the larvae sting and suck the hosts until they are fully engorged. In the second stage, the engorged larvae are placed into a culture tube to finish the development of the next stages, nymphochrysalis, nymph, imagochrysalis and adult. After "indirect mating" with the male, the pregnant female lays its eggs in the tube and then the eggs hatch the newborn larvae (newly hatched larvae). In the artificial culture of $L$. deliense, several key factors should be properly selected and controlled, with recommen- dations as follows: suitable temperature $18-28^{\circ} \mathrm{C}$, critical temperature $13-35^{\circ} \mathrm{C}$, optimum temperature $23-25^{\circ} \mathrm{C}$, optimum RH $80-100 \%$ or $95-100 \%$, and the most ideal temperature $25 \pm 1^{\circ} \mathrm{C}$ for the long cultivation. Under the appropriate temperature and humidity, and with enough food, L. deliense usually undergo 3-4 generations in 1 year. Under the laboratory temperature of $20 \pm 1^{\circ} \mathrm{C}$, the lifespan of $L$. deliense is usually as long as 2, 3 years and, occasionally, even up to $4-5$ years. The temperature is the most important factor influencing the lifespan of the mite. When the lifespan is beyond 3-5 years, the fecundity of the female is lost. The flea eggs are recommended as the food of the nymphs and adults. One flea egg is given to feed one nymph every day and 2 eggs for one adult. The food supply decreases with the increase of the mite's age.

\section{CONFLICT OF INTEREST}

The authors declare they have not conflict of interest.

\section{REFERENCES}

1. Strickman D. Scrub typhus. In Ashford RW, Service MW eds. The Encyclopedia of Arthropod-Transmitted Infections. New York, USA. CABI Publishing. 2001, pp 456-462.

2. Zhan YZ, Guo XG, Speakman JR, Zuo XH, Wu D, Wang QH, Yang ZH. Abundances and host relationships of chigger mites in Yunnan province, China. Med Vet Entomol 2013; 27: 194-202.

3. Candasamy S, Ayyanar E, Paily K, Karthikeyan PA, Sundararajan A, Purushothaman J. Abundance \& distribution of Trombiculid mites \& Orientia tsutsugamushi, the vectors \& pathogen of scrub typhus in rodents \& shrews collected from Puducherry \& Tamil Nadu, India. Indian J Med Res 2016; 144: 893-900.

4. Takada N, Yamamoto S, Taira K, Fujita H, Tkahashi M, Ando S, Kadosaka T. High endemicity of deliense-chigger found out on Miyako islands where tsutsugamushi disease cases etiologically associated with Taiwan were diagnosed. J Acarol Soc Jpn 2011; 20: 47-48 (in Japanese).

5. Traub R, Wisseman CL Jr, Ahmad N. The occurrence of scrub typhus infection in unusual habitats in west Pakistan. Trans R Soc Trop Med Hyg 1967; 61: 23-57.

6. Takada N. Tsutsugamushi disease originally occurring in Okinawa. Mod Med Lab 2013; 41: 76-79 (in Japanese).

7. Chakraborty S, Sarma N. Scrub typhus: an emerging threat. Indian J Dermatol 2017; 62: 478-485.

8. Walch EW. Over Trombicula deliensis n. sp., vermoedelijke overbrengster der Pseudotyphus, en andere Trombiculae van Deli (Eerste Mededeeling). Geneeskundig Tijdschrift voor Nederlandsch-Indië 1922; 62: 530-588.

9. Womersley H. The scrub-typhus and scrub-itch mites (Trombicu- 
lidae, Acarina) of the Asiatic-Pacific region. Rec S Aust Mus 1952; 10: $1-435$

10. Vercammen-Grandjean PH, Langston RL. The Chigger Mites of the World (Acarina: Trombiculidae \& Leeuwenhoekiidae). III. Leptotrombidium Complex. San Francisco, USA. George Williams Hooper Foundation. 1976.

11. Barrow GJ, Domrow R, Derrick EH. Rocky creek, an outlying focus of scrub typhus in north Queensland. Australas Ann Med 1963; 12: 166-170.

12. Li J, Wang D, Chen X. Trombiculid Mites of China: Studies on Vector and Pathogen of Tsutsugamushi Disease. Guangzhou, China. Guangdong Science and Technology Publishing. 1997, pp 1-157 (in Chinese).

13. Fernandes S, Kulkarni SM. Studies on the trombiculid mite fauna of India. Rec Zool Surv India 2003; 212: 1-539.

14. Stekolnikov AA. Leptotrombidium (Acari: Trombiculidae) of the world. Zootaxa, 2013; 3728: 1-173.

15. Fletcher W, Lesslar JE, Lewthwaite R. The aetiology of the tsutsugamushi disease and tropical typhus in the federated Malay states. Trans R Soc Trop Med Hyg 1928; 22: 161-162.

16. Mehta DR. Studies on typhus in the Simla hills. part viii. ectoparasites of rats and shrews with special reference to their possible role in the transmission of typhus. Indian J Med Res 1937; 25.

17. Heaslip WG. Tsutsugamushi fever in north Queensland, Australia. Med J Australia 1941; 1: 380-392.

18. Davis GE, Austrian RC, Bell EJ. Observations on tsutsugamushi disease (scrub typhus) in Assam and Burma. the recovery of strains of rickettsia orientalis. Am J Hyg 1947; 46: 268-286.

19. Geng ML, Guo XG. Advances in the study of Leptotrombidium deliense in China. J Pathogen Biol 2014; 9: 763-765 (in Chinese).

20. Wen T, Chen J. A new subspecies of Leptotrombidium deliense from Penghu, Taiwan Province (Acariformes: Trombiculidae). In Wen T ed. Sand Mites of China (Acariformes: Trombiculidae and Leeuwenhoekiidae). Shanghai, China. Xue Lin Publ House. 1984, pp 175-176 (in Chinese).

21. Zhao SX, Tang FT, Mo GY. A study of the chigger mites and their hosts from Xisha Archipelago, China (Acarina: Trombiculidae). Acta Entomologica Sinica 1986; 29: 96-100 (in Chinese).

22. Suputtamongkol Y, Suttinont C, Niwatayakul K, Hoontrakul S, Limpaiboon R, Chierakul W, Losuwanaluk K, Saisongkork W. Epidemiology and clinical aspects of rickettsioses in Thailand. Ann NY Acad Sci 2009; 1166: 172-179.

23. Traub R, Wisseman Jr. CL. The ecology of chigger-borne rickettsiosis (scrub typhus). J Med Entomol 1974; 11: 237-303.

24. YÜ ES, Wu HY. Study on morphological and biological differences between two types of Trombicula deliensis Walch. Acta Entomologica Sinica 1959; 9: 65-74 (in Chinese).

25. Lin H, Dong WG, Song WY, Zou YJ, Fan R, Guo XG. The morphological comparison of Leptotrombidium rubellum and Leptotrombidium deliense. J Dali Univ 2016; 1: $62-66$ (in Chinese).

26. Ye YB, Wang DQ. Preliminary studies on the chromosomes banding of some chigger mites. Acta Entomologica Sinica 1992; 35: 165-170 (in Chinese).
27. Sun YM, Wang DQ. Comparison on esterase isozyme of chigger mites. Acta Entomol Sinica 1988; 31: 401-406 (in Chinese).

28. Kadosaka T, Fujiwara M, Kimura E, Kaneko K. Hybridization experiments using 3 species of the scrub typhus vectors, Leptotrombidium akamushi, L. deliense and L. fletcheri. Med Entomol Zool 1994; 45: 37-42.

29. Varma RN. A note on a reliable distinguishing feature between the two closely allied scrubtyphus vectors, Leptotrombidium $(L$.) deliense and L. (L.) akamushi. Indian J Med Sci 1972; 26: 430-431.

30. Nadchatram M, Dohany AL. Leptotrombidium (Leptotrombidium) umbricola, new species, a probable vector of scrub typhus in peninsular Malaysia. Jpn J Med Sci Biol 1980; 33: 277-282.

31. Takahashi M, Misumi H, Noda S. Leptotrombidium suzukii (Acari, Trombiculidae): a new species of chigger mite found on Apodemus speciosus (rodentia, muridae) on Nakanoshima Island in the Tokara Islands, Kagoshima Prefecture, Japan. Bull Natl Mus Nat Sci 2014; 40: 191-199.

32. Tsurusaki N, Takahashi M. Chromosomes of 4 species of the chigger mites from the Ryukyu Islands, with notes on geographic or intercolonial variation of the chromosome number in Vatacarus ipoides and Leptotrombidium deliense (Acari: Prostigmata: Trombiculidae). Abstract book of the 14th International Congress of Acarology; 2014 July 14-18; Kyoto, Japan. 2014, pp 149.

33. Varma RN, Mahadevan B. Laboratory colonisation of the scrub typhus vector, Leptotrombidium deliense (L.) and some observations on its life history and habits. Indian J Entomol 1974; 34: 300-306.

34. Krishnan KV, Smith ROA, Bose PN, Neogy KN, Roy BKG, Ghosh M.Transmission of rickettsia orientalis by the bite of the larvae of trombicula deliensis. Ind Med Gaz 1949; 84: 41-43.

35. Xu BK, Chen XT. The relationship between the temperature and the development of Trombicula akamushi var. deliensis. Acta Microbiologica Sinica 1960; 8: 1-7 (in Chinese).

36. Audy JR. The ecology of scrub typhus. In May JM ed, Studies in Disease Ecology. New York, USA. Hafner Publishing. 1961, pp 389-432.

37. Xu BK, Li JC, Chen XT. Effects of ${ }^{60} \mathrm{CO} \gamma$-Ray on Trombicula akamushi var. Deliense, including morphology, function and genetic changes. Acta Parasitol Sinica 1965; 2: 404-411 (in Chinese).

38. Chen HT, Xu BK. The age of the adult Trombicula akamushi var. deliensis in relation to the number of larvae produced. Acta Zoologica Sinica 1962; 14: 68-73 (in Chinese).

39. Kaufmann T, Traub R. Preliminary notes on parthenogenesis in a species of trombiculid mite, leptotrombidium arenicola traub, 1960 (acarina: trombiculidae). J Med Entomol 1966; 3: 256-258.

40. Xu BK, Li JC, Chen XT. Studies on Trombicula akamushi var. Deliense with ${ }^{32} \mathrm{P}$ markers. Acta Parasitol Sinica 1965; 3: 118-124 (in Chinese).

41. Peng PY, Guo XG, Ren TG, Dong WG, Song WY. An updated distribution and hosts: trombiculid mites (Acari: Trombidiformes) associated with small mammals in Yunnan province, southwest China. Parasitol Res 2016; 115: 1923-1938.

42. Peng PY, Guo XG, Ren TG, Song WY, Dong WG, Fan R. Species diversity of ectoparasitic chigger mites (Acari: Prostigmata) on 
small mammals in Yunnan Province, China. Parasitol Res 2016; 115: 3605-3618.

43. Bell PJ, Whelan PI. A scrub typhus vector Leptotrombidium deliense (Walch) (Acari: Trombiculidae) on rats in Litchfield park, northern territory, Australia. Aust J Entomol 1993; 32: 207-208.

44. Roberts LW, Muul I, Robinson DM. Numbers of Leptotrombidium (Leptotrombidium) deliense (Acarina: Trombiculidae) and prevalence of Rickettsia tsutsugamushi in adjacent habitats of peninsular Malaysia. Southeast Asian J Trop Med Public Health 1977; 8: 207-213.

45. Mahajan SK. Scrub typhus. J Assoc Physicians India 2005; 53 : 954-958.

46. Rodkvamtook W, Gaywee J, Kanjanavanit S, Ruangareerate T, Richards AL, Sangjun N, Jeamwattanalert P, Sirisopana N. Scrub typhus outbreak, northern Thailand, 2006-2007. Emerg Infect Dis 2013; 19: 774-777.

47. Sharma PK, Ramakrishnan R, Hutin YJ, Barui AK, Manickam P, Kakkar M, Mittal V, Gupte MD. Scrub typhus in Darjeeling, India: opportunities for simple, practical prevention measures. Trans $\mathrm{R}$ Soc Trop Med Hyg 2009; 103: 1153-1158.

48. Varma RN. Prevalence of Leptotrombidium deliense, the scrub typhus vector, in the eastern Himalayas. Nature 1969; 222: 984-985.

49. Saxena VK. On the presence of Leptotrombidium (L.) deliense in district Bastar, Madhya Pradesh. J Commun Dis 1983; 15: 290-291.

50. Frances SP, Watcharapichat P, Phulsuksombati D, Tanskul P, Linthicum KJ. Seasonal occurrence of Leptotrombidium deliense (Acari: Trombiculidae) attached to sentinel rodents in an orchard near Bangkok, Thailand. J Med Entomol 1999; 36: 869-874.

51. Varma RN, Mahadevan B. The bionomics and vector potential of the scrub typhus vector Leptotrombidium (L.) deliense and other trombiculid populations in eastern Himalayas, India. Indian J Med Sci 1973; 27: 900-919.
52. Frances SP, Watcharapichat P, Phulsuksombati D. Development and persistence of antibodies to Orientia tsutsugamushi, in the roof rat, Rattus rattus, and laboratory mice following attachment of naturally infected Leptotrombidium deliense. Acta Trop 2000; 77: 279-285.

53. Frances SP, Watcharapichat P, Phulsuksombati D. Vertical transmission of Orientia tsutsugamushi in two lines of naturally infected Leptotrombidium deliense (Acari: Trombiculidae). J Med Entomol 2001; 38: 17-21.

54. Frances SP, Linthicum KJ. Experimental infection and transmission of Orientia tsutsugamushi in adult Leptotrombidium deliense following inoculation with cultured rickettsiae. Int J Acarol 2002; 28: 267-272.

55. Hong N, Jiacan C, Tiansheng C. Studies on Rickettsia tsutsugamushi propagation in Leptotrombidium deliense and its transovarian transmission by DNA amplification using polymerase chain reaction technology. Acta Parasitol Med Entomol Sinica 1994; 1: 48-53.

56. Shirai A, Ram S, Gan E, Lewis GE Jr, Kanda T, Chiang GL, Groves MG. Comparative studies on the karyotypes of Leptotrombidium deliense, L. fletcheri, and L. arenicola (Acari: Trombiculidae). J Med Entomol 1984; 21: 616-617.

57. Jiacan L. Experimental hybridization of red and white Leptotrombidium deliense (Acarina: Trombiculidae). Chin J Zoonoses 1990; 6: 15-17 (in Chinese).

58. Shao R, Barker SC, Mitani H, Takahashi M, Fukunaga M. Molecular mechanisms for the variation of mitochondrial gene content and gene arrangement among chigger mites of the genus Leptotrombidium (Acari: Acariformes). J Mol Evol 2006; 63: 251-261.

59. Xi Z, Li J, Zheng X, Yan X. Comparative studies on molecular techniques for detecting Rickettsia tsutsugamushi in Leptotrombidium deliense and mice. Syst Appl Acarol 1999; 4: 15-20. 